\title{
A GLOBALIZÁCIÓ ÉS A KREATÍV GAZDASÁG FELÉRTÉKELÖDÉSE
}

\author{
(Globalisation and the Revaluation of Creative Economy)
}

\section{DOBÓ ESZTER}

Kulcsszavak:

globalizáció kultúra kreativiparágak szellemi töke

Napjaink globalizálódó világában a kulturális és kreativ iparágak felértékelödésének lehetünk tanúi. A világgazdaságban tapasztalható szerkezetváltás a szellemi töke, a kreativitás fokozott elötérbe helyezését vonta maga után. A produktív gondolkodás által létrehozható értéktartalmak azonban kulturális folyamatok eredményei. A kultúra elótérbe helyezése tehát gazdasági kényszerré vált a posztindusztriális társadalmak válságkezelési stratégiáiban, a versenyképesség fokozásában és egyben a társadalmi kohézió erôsitésében.

\section{Bevezetés}

A tanulmány a kreatív iparágak egyre erősebben megmutatkozó jelentőségének hátterét vizsgálja. A globalizáció időszakának beköszöntével, az információs technológiák hozzáférhetőségének javulásával, a globális trendek, kultúrák követésének előnyös és hátrányos hatásaival való szembehelyezkedéssel párhuzamban a lokális értékek felértékelődésének is tanúi vagyunk. A lokalitás ezen a ponton számunkra egyet jelent a helyi hagyományokból, tradíciókból táplálkozó értékközvetítéssel, a humán, természeti és tárgyi produktumok iránti szükségletek felemelkedésével.

A globális folyamatok azonban egy újfajta munkamegosztás felálítását is kialakították. A fordizmus tömegtermelése, a tárgyi tökébe való beruházás mindenhatósága a társadalom előrehaladásának alapját a nyersanyagok bőségében látta. A modern posztfordista gazdaság ezzel ellentétben a kutatás-fejlesztést, a müszaki előrehaladást, az innovatív, megújulni képes gondolkodást tekinti napjaink legfőbb versenyképes eszközeinek. A humán tőke ilyen mérvú felértékelödése előtérbe állította annak fejleszthetöségi eszközeit. A kreativitás, a produktív gondolkodás alakíthatóságának vizsgálatai a pszichológia területéről egyre inkább a közgazdasági gondolkodás újfajta motiválóivá váltak.

A kreatív gazdaság és annak magágazatai révén a kulturális iparágak eddig nem tapasztalt ütemü növekedését figyelhetjük meg a nyugati, fejlett demokráciákban. Számos, az említett iparágak forradalmát hirdető tanulmány a jövö sikeres térségeit is ezen ágazatok vonzási képességének függvényében határozza meg (Florida 2002; Enyedi 2005). 
A szellemi tőkéért folytatott harcban olyan országok is sikeresen léphetnek a világverseny porondjára, amelyek „csupán” belső, helyi erőfesźtésekkel, a hagyományokból fakadó komparatív elönyök kiaknázásával képesek gazdasági erejüknek esélyt adni.

\section{A globális korszak és a szellemi töke}

A 20. század első felének fordista gazdasága az első nagy iparszerkezeti váltást követỏen a gép- és a vegyipart tette vezetö ágazatokká, az egy vállalaton belül müködö technológiai lánc pedig a tömegtermelést tekintette a versenyképesség forrásának. A múlt század második fele három nagy szerkezeti átalakulást hozott (Enyedi 2007):

- A munkafolyamatok technológiai fejlődése tapasztalható, ami maga után vonta az ipari munkaeröigény csökkenését. A közlekedés fejlödése hozzájárult a különbözỏ munkafázisok feldarabolásához, széttelepítéséhez. A fordizmus végével a piac gyorsan változó igényei háttérbe szorították a tömegtermékek gyártását.

- A posztindusztriális korszak a városi gazdaságokban háttérbe szorította az ipart, és mind a foglalkoztatásban, mind a tőkeforgalomban a szolgáltató szektor vált domináns ágazattá. A szolgáltatások egy része természetesen a termelỏ ágazatok kiszolgálója maradt, de egyben megjelentek az egyre növekvő szabadidőhöz kapcsolódó szolgáltatások is (turizmus, kulturális és szolgáltató iparágak). Mind jobban kezdenek felértékelődni olyan közszolgálati területek, mint az oktatás, mely a közelgő szellemi tôke-igény felértékelödésének irányába hat.

- A napjainkra jellemző információs robbanás, a regionalizáció kora, a globális világrendszerben való nyitott részvétel az egyediséget és a humán tőke minöségét állította a versenyképesség középpontjába. Az említett két tényezö felértékelődése logikus következményként vonta maga után a kultúra elötérbe kerülését. ${ }^{1}$ A terület fontosságát támasztja alá még a fogyasztási szükségletek módosulása is. A fogyasztás egy számottevő része már nem csupán hasznossági alapon történik, hanem kulturális szempontok alapján. A szolgáltatásoknak a posztmodern társadalmakban nagyrészt nem gyakorlati, hanem kulturális-szimbolikus jelentöségük van.

A humán tỏke minőségének felértékelődése mérőeszközzé tette a kreativitást, mint mára divatossá vált fogalmat. A kreativitás fejleszthetőségének felismerése pedig versenyágazattá emelte az oktatási és kulturális intézményrendszereket.

\section{A kreativitás felértékelödése}

A kreativitás vizsgálataiban való elmélyülés elengedhetetlenné teszi a pszichológiai alapvetések részbeni ismeretét. Ahhoz, hogy érzékletesebben tudjuk a téma fontosságát bemutatni, kihagyhatatlan a fogalmi rendszerekben való tisztánlátás. A kreativitás- 
vizsgálatok elindítói ugyanis a pszichológia területéről kerültek ki, és azt a labdát, amit ök feldobtak lassan hatvan évvel ezelött, napjaink közgazdászai ütik le.

A kreativitás legtágabb értelemben minden, amit az ember csinál. Minden kultúra, amit az ember teremtett, ennek az eredménye (Vitányi 2000). Ilyen tekintetben tehát a kultúra megegyezik a kreativitással. ${ }^{2}$ Ahhoz azonban, hogy értelmezhetỏvé váljék napjainkban tapasztalt dominanciája, el kell szakadnunk a tágan értelmezett fogalomtól. Hiszen így a késsel-villával evést és a kerékpározást is kreatív dolognak kellene, hogy tekintsük.

A kreativitásvizsgálatok az ötvenes években kezdődtek, és J.P. Guilford nevéhez és kutatásaihoz kapcsolódnak. A húszas, harmincas évek német pszichológiai irodalmában már megjelentek olyan fogalmak, mint az „alkotóképesség” és „produktív gondolkodás", azonban a terület akkoriban még a szakmában is perifériára szorult. $\mathrm{Az}$ amerikai kutató évekkel később a köztudatban is ismerté tette a kreativitás fogalmát. Az akkoriban általánosan elfogadott intelligencia fogalmat szükségszerünek tartotta egy új területtel kiegészíteni. Vizsgálatai során arra a tapasztalatra mutatott rá, hogy az alkotó emberek sok olyan mentális képességgel rendelkeznek, melyeket a hagyományos intelligenciatesztek nem tudnak mérni, holott jelentöségükhöz nem fér kétség. Guilford felmérései igazolták, hogy egy bizonyos szint felett az intelligencia mértéke már nem tudja lényegesen befolyásolni az alkotások létrejöttét, tehát feltételezhető volt egy másik tényező, a kreativitás beiktatása, ami az azonos intelligenciájú emberek alkotásaiban megmutatkozó különbségért lett felelős. A kutatások rávilágítottak arra, hogy a felgyorsult ipari-tudományos fejlödés követelményeinek csak az idejében felismert és fejlesztett emberi (alkotó) képességek figyelembevételével lehet eleget tenni. Ezen a ponton a pszichológiai kutatások addigi eredményei találkoztak a társadalom és a gazdaság igényeivel (Klein B.-Klein S. 2001).

A kreativitás bizonyos fokig minden ember sajátja. Fokozatait tekintve a reprodukciót, a generativitás különböző fokozatait és a „féktelen alkotást” jelenti. A reprodukálás lényegében megegyezik a kreativitás legszélesebb értelmezésével. Az ember azáltal halad előre fejlődésében, szocializációjában, hogy képes a tanult dolgok reprodukálására. A generativitás az alkotókészség magasabb szintje, mely szintén minden ember sajátja, ám nem egyforma mértékben. Mindannyian képesek vagyunk véges számú szabályok ismeretében végtelen számú variánsok megalkotására, azonban az alkotások értékelésében már különbözhetünk egymástól. A végső fokozat, a „féktelen alkotás” képessége kevés szerencsés adománya, mely többségében a művészek, tudósok, kutatók sajátja.

Kiegészítve a pszichológiai kutatások eredményeit, számos vonatkozásban szükséges az agyi funkciók néhány érdekes aspektusára is figyelmet szentelni (1. ábra). 


\section{1. ÁBRA}

Az aszimetrikus emberi agyféltekék müködésmegoszlása (The Function-distribution of Asymmetric Human Cerebral Hemisphere)

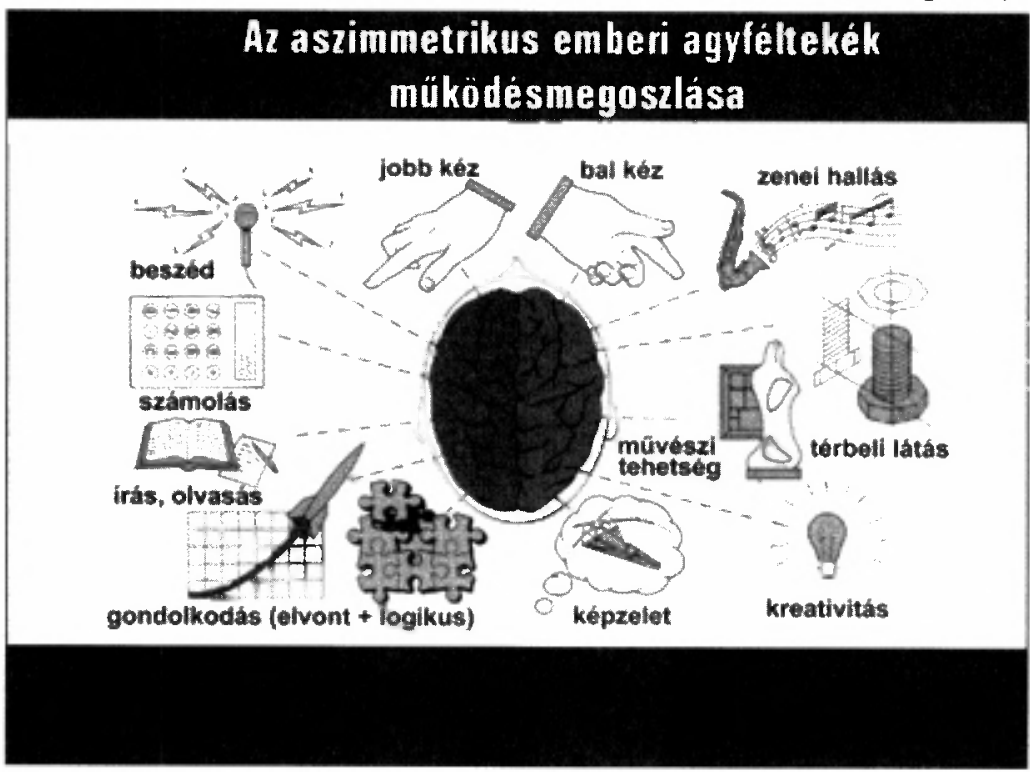

Forrás: www.mindentudas.hu

Látható, hogy a képzelőerő, a kreativitás képessége jobb agyféltekei funkciók, melyek azonos területen foglalnak helyet a magas-kulturális befogadóképességekkel. A számtalan pedagógiai vizsgálat pedig csak alátámasztani tudja ezen funkciók egymásra hatásának jelentőségét az oktatásban, legfőképpen az alapfokú képzési intézményekben. ${ }^{3}$ A kreativitás egy genetikai adomány, viszont fejleszthetö, mely igény még soha nem vált annyira időszerüvé és sürgető kérdéssé, mint napjaink globalizálódó világában.

A kreatív, innovatív ötletek azonban nem egy légüres térben születnek meg. A produktív gondolkodás az egyén teljesítménye mellett még legalább két másik tényezőtől fưgg: a kulturális közegtől, mely az uralkodó ízlés, a társadalom tudatában jelen lévő alkotások hagyományok összessége, illetve az ezt kiegészítő társadalmi mezőtől, amely lehetővé teszi, támogatja, vagy éppen megakadályozza a megfelelő kulturális közeg átalakulását a kreatív alkotásokon keresztül. „A kreativitás folyamata tehát az egyén, a kulturális közeg és a társadalmi mező interakciójának az eredménye. (...) A kreativitás így nem pusztán az egyének, hanem az ezek teljesítményéről az adott kulturális közegben ítéletet hozó társadalmi tényezők és az egyén közös terméke." (Tájékoztató... én.) Kondor Zsuzsanna szerint a születendő kreatív ötlet részben feltételezi korábbi ismeretek, eredmények befogadását, továbbélése azonban attól függ, hogy az mennyire illeszthetö be az adott tudományos és társadalmi-kulturális értékrendbe. „A tudományos eredmény újszerüségének és a tudo- 
mányos közösség fogékonyságának harmonikus aránya biztosíthatja, hogy az eredmény integrálódhasson, és kreatívnak minősülhessen." (Kondor én.)

A kreatív iparágak esetében a végsỏ szót tehát a piac mondja ki. (Véleményünk szerint ezért tapasztalható sokszor az, hogy a magányos zseniket, mủvészeket, tudósokat gyakran nem a saját koruk igazol provokatív, forradalmi gondolataikért, alkotásaikért, hanem csak az elkövetkezô időszakok társadalma.)

\section{A kreativitás gazdasági súlya}

A korábbi évszázadokban egy adott ország, térség gazdasági fejlettsége a mezögazdaság, az ipar termelékenységétől, a munkaerỏ mennyiségétől, a klasszikusan jól definiálható tényezök szerepétől függött. A 20 . század végétől a versenyképesség egyre inkább meghatározó eszköze a humán erőforrás lett. Az ember hozzájárulása a helyi gazdaságok fejlödéséhez nem csupán mennyiségi alapon történt, hanem minöségi tényezők alapján. A szellemi tőke egy folyamatosan megújulni képes erőforrásként végtelen lehetőségek és korlátlan növekedés lehetőségét jelenti napjaink gazdaságfejlesztésében. Ezen eszköz hozzáadott értékét viszont a kreatív, innovatív gondolkodás lehetősége jelenti, melynek fejleszthetősége soha nem látott mértékben értékelte fel a kreatív iparágak jelentőségét.

A humán erőforrások felértékelődése mellet nem szabad azonban megfeledkeznünk egy másik fontos tényezőröl, amely szintén a kreatív gazdaság napjainkra tapasztalt fontosságát helyezi elötérbe, mégpedig az egyre növekvő szabadidőről és az arra elkölthető pénzösszegről. Ahogy azt már fentebb említettük, a fogyasztás szerkezetváltása átformálta a szükségletek kielégitésének kosarát, a hagyományos alapigényeket kielégítö termékek mellett egyre nagyobb mértékben jelenik meg a kulturális-szimbolikus termékek birtoklásának vágya, igénye. Ehhez nyilván elsỏsorban a globalizáció „main stream” trendjeihez való hozzáférés adta a lehetőséget, mely a világháló által a Glóbusz jelentös részét a "fó áramba” olvasztotta, és hígított formában hozzáférhetővé, illetve integrálttá tette az úgynevezett „globális kultúrát".

A tudásgazdaság fenntartható növekedésének függvénye az oktatásba, a kultúrába, az innovációba, a kommunikációs technológiába és az azt segitő intézményi környezetbe való befektetés. A versenyzö nemzetállamok számára mind egyértelmübben látható, hogy a sikereiket és megörzött pozíciójukat a "tudás" (tudomány, innováció, humán erőforrások, kreativitás) és az „információ” fejlesztésének köszönhetik (Z. Karvalics-Kollányi 2006).

E tanulmányban a humán tőke szempontjából kiemelten vizsgáljuk a kreativitást, a kreatív iparágak felértékelődését. A kreatív iparágak azok a tevékenységek, melyek gyökere az egyéni kreativitásban, alkotókészségben, képzettségben és képességekben rejlik, és amelyek a szellemi tulajdon létrehozásán és felhasználásán keresztül (a szellemi jogdíj, illetve a szabadalmi bejegyzés által) képesek munkahelyeket és ezáltal jólétet teremteni (www.matisz.hu).

Az egyedi szellemi és tárgyi produktumok létrehozására épülő iparágak csoportosítása, illetve a csoportok elnevezése a téma kutatóinak tekintetében meglehetősen színes képet mutat. Az általunk ábrázolt felosztás nagyrészt követi a különbözö 
felosztásokat, de kiegészül még néhány nem piaci alapon múködő területtel. A felállított piramis az alapvetően piaci alapon müködő iparágak hierarchiáját ábrázolja, a kulturális iparágaktól haladva az összes szerzői jogú iparág felé. Ezeket az iparágakat szokás összességében tartalomiparágaknak nevezni, de sokan a Kreativ Iparágak elnevezéssel illetik a teljes, a piramis által bemutatott szektort.

Az üzleti alapon müködő tartalomipari ágazatok mellett nem kerülhetjük el az ahhoz szorosan kapcsolódó szocio-kulturális közszolgálati és civil irányítással múködő területeket sem, mint az oktatás, közmúvelődés (könyvtárak, múzeumok, levéltárak), melyekhez való hozzáférés biztosítása elengedhetetlen alap a piaci alapon müködő szektorok versenyképes müködéséhez. A másik alap a környezet, a tradíciók, hagyományok, a hozott kultúrák leképeződéseinek terei, a kulturális, illetve épített örökség (2.ábra).

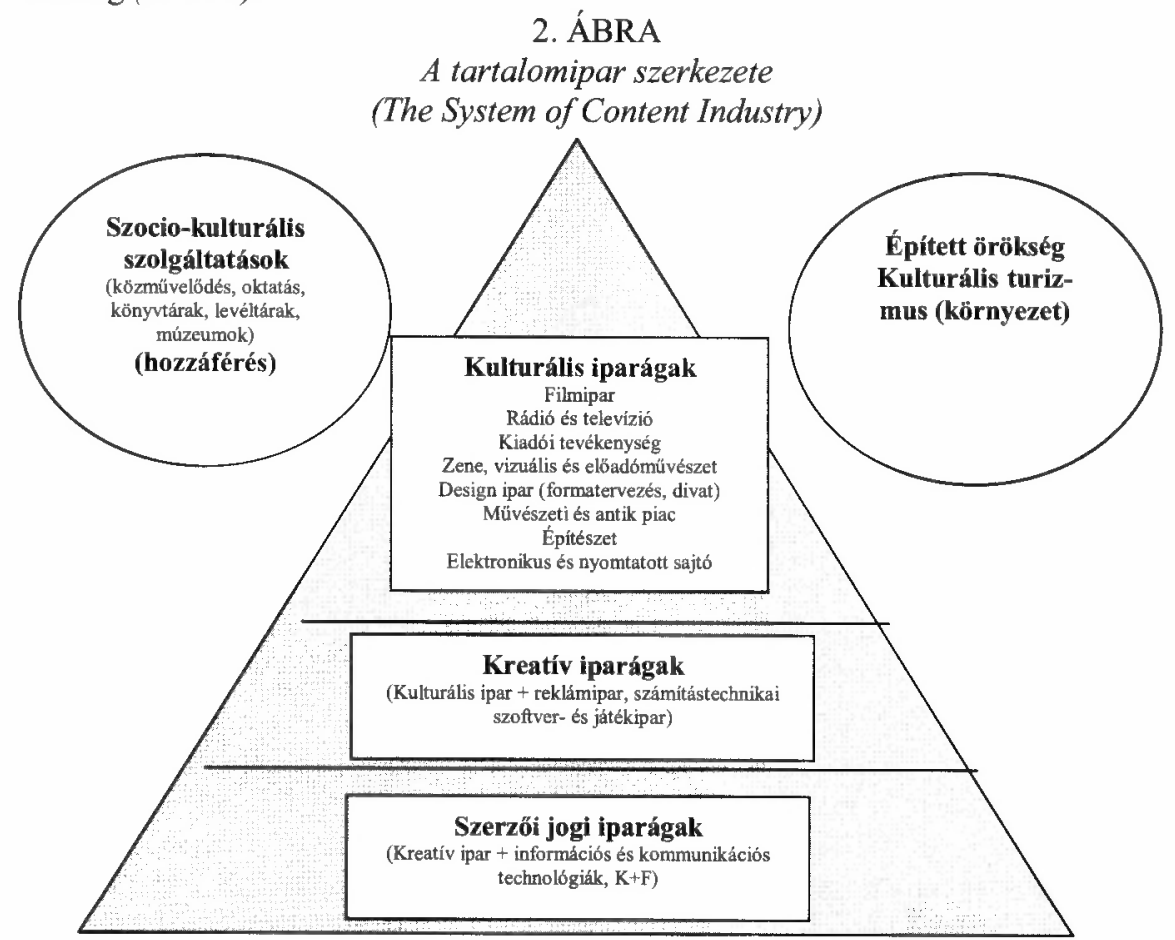

Forrás: Hartley (2005) alapján saját szerkesztés.

A kreatív iparágak gazdaságon belüli egyre dominánsabbá váló szerepét - köszönhetöen a szélesebb körủ statisztikai adatszolgáltatásnak - leginkább az Egyesült Királyság példája mutatja be, ahol az ágazat hozzájárulása 2004-ben a bruttó hozzáadott értékhez 7,3\% volt. 1997 és 2004 között a terület éves átlagban 5\%-kal növekedett, míg a teljes gazdaság átlagosan 3\%-kal. 2004-ben a kreatív iparágak exportja 13 milliárd font volt, ami a teljes termék és szolgáltatás kivitel 4,3\%-a (a szektoron belül a szoftver, a számítógépes játékok és az elektronikus kiadványszerkesztés az export 36\%-át fedte le). A foglakoztatásban az ágazat 1,8 millió föt alkalmazott, éves növekedési üteme pedig 2\% volt 1997 és 2005 között (a szoftver, a számítógépes 
játékok és az elektronikus kiadványszerkesztés területén 6\%). 2005-ben 117500 vállalkozás (az összes 7,2\%-a) volt jelen az iparágban (Creative Industries... 2006).

A kreatív gazdaság az Európai Unión belül is a gazdasági növekedés motorját jelenti. 1999-2003 között a forgalom európai átlagos növekedése 8,1\%, a foglalkoztatásé pedig 1,85\% volt 2002 és 2004 között. A 3. és 4. ábrákon látható az ágazat helyzete a többi stratégiai iparág mellett a forgalom és a foglakoztatás tekintetében. A 2002-es adatok meghatározása a majdani 2004-es csatlakozásban részt vevö országok számbavételével együttt történt.

\section{3. ÁBRA}

A kreativ iparágak forgalma az EU25-ben, 2002

(Turnover of Creative Sectors in EU25, 2002)

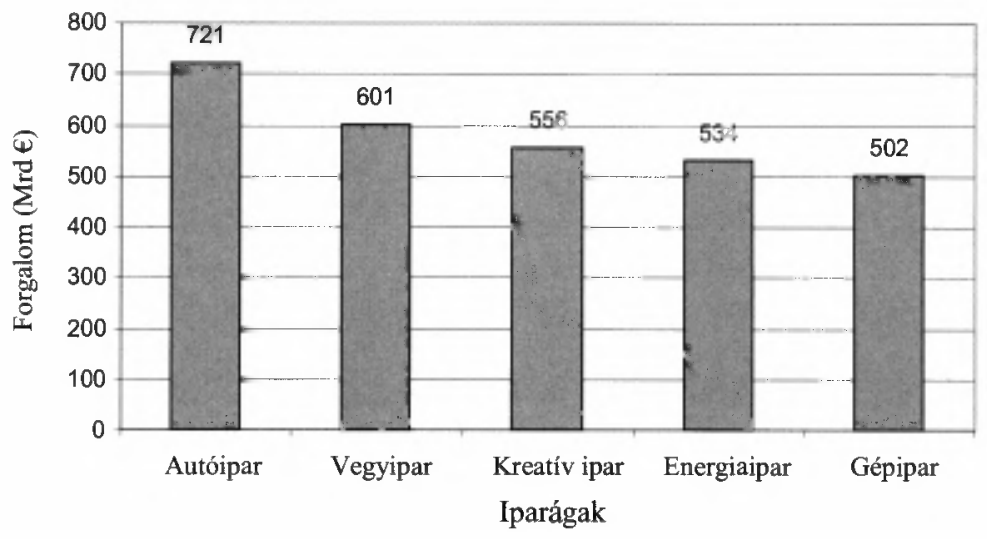

Forrás: Söndermann (2007).

\section{4. ÁBRA}

A kreativ iparágakban foglalkoztatottak száma az EU25-ben, 2002

(Employment in Creative Sectors in EU25, 2002)

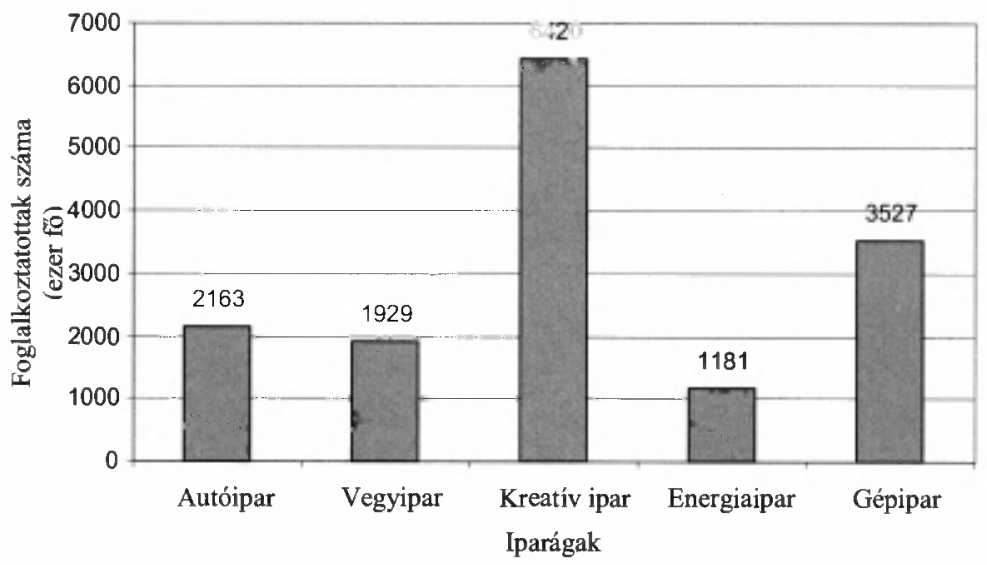

Forrás: Söndermann (2007). 
A tartalomipar magyarországi helyzetéről a Magyar Szabadalmi Hivatal vizsgálatai nyújtanak képet (Penyigey-Munkácsy 2005). Az adatok alapján a szerzői jogi iparágak együttes bruttó hozzáadott értéke 987 milliárd forint volt 2002-ben, ami a nemzetgazdaság bruttó hozzáadott értékének 6,67\%-val egyezett meg. Az ágazaton belül az elsődleges szerzői jogú iparágak bruttó hozzáadott értéke 586 milliárd forintot tett ki, ami a GDP 3,96\%-át adta.

A szerzői jogi alapú ágazatok hozzájárulása a bruttó kibocsátáshoz 3412 milliárd forint volt, ami a nemzetgazdasági kibocsátás 9,68\%-át tette ki. Ezen belül az elsődleges szerzői jogi ágazatok a nemzetgazdaság bruttó kibocsátásának 3,95\%-át adták. Az összes szerzői jogi alapú iparágakban foglalkoztatottak az összes foglalkoztatott 7,10\%-át, az elsődleges szerzői jogi alapú ágazatok pedig 4,15\%-át tették ki. Öszszességében a teljes szerzỏi jogi ipar a magyar gazdaság teljesítményének 7-9\%-át (az elsődleges 4\%-át) képviselte.

Más ágazatokkal való összehasonlításban az ágazatok GDP-n belüli súlya tekintetében tekintélyes helyet foglalnak el a gépipar $(7,53 \%)$, a vegyipar (4,43\%) vagy az épitöipar (5,32\%) mellett (5., 6. ábra).

\section{5. ÁBRA}

Szerzői jogú ágazatok súlya 2002-ben, a magyar gazdaságban a GDP-hez való hozzájárulás alapján (\%)

(Contribution of Copy-right Industries to Hungarian GDP, 2002)

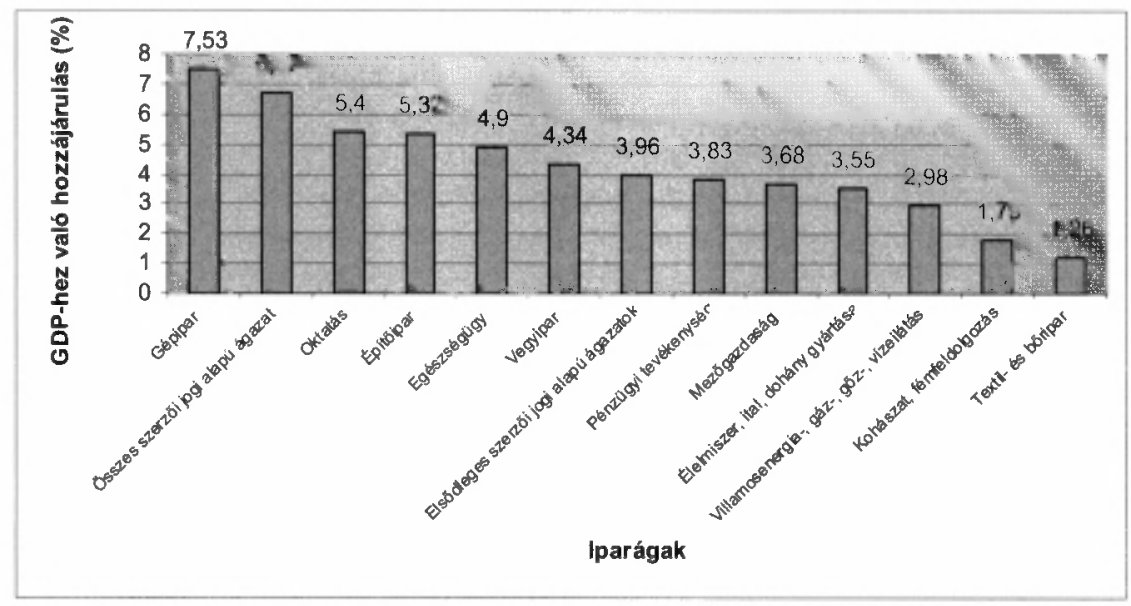

Forrás: Penyigey-Munkácsy (2005).

Nemzetközi összehasonlításban az elsődleges szerzői jogi iparágak GDP-hez való hozzájárulása Nagy-Britanniában $(7,1 \%)$ és az Egyesült Államokban $(5,98 \%)$ volt a legmagasabb. Magyarország helyzete az adatok alapján kedvezönek mondható (7. ábra). 
Dobó Eszter : A globalizáció és a kreatív gazdaság felértékelődése.

Tér és Társadalom 21. évf. 2007/3. 89-102. p.

\section{6. ÁBRA}

Szerzői jogú ágazatok súlya 2002-ben, a magyar gazdaságban a foglalkoztatáshoz való hozzájárulás alapján (\%)

(Contribution of Copy-right Industries to Hungarian Employment, 2002)

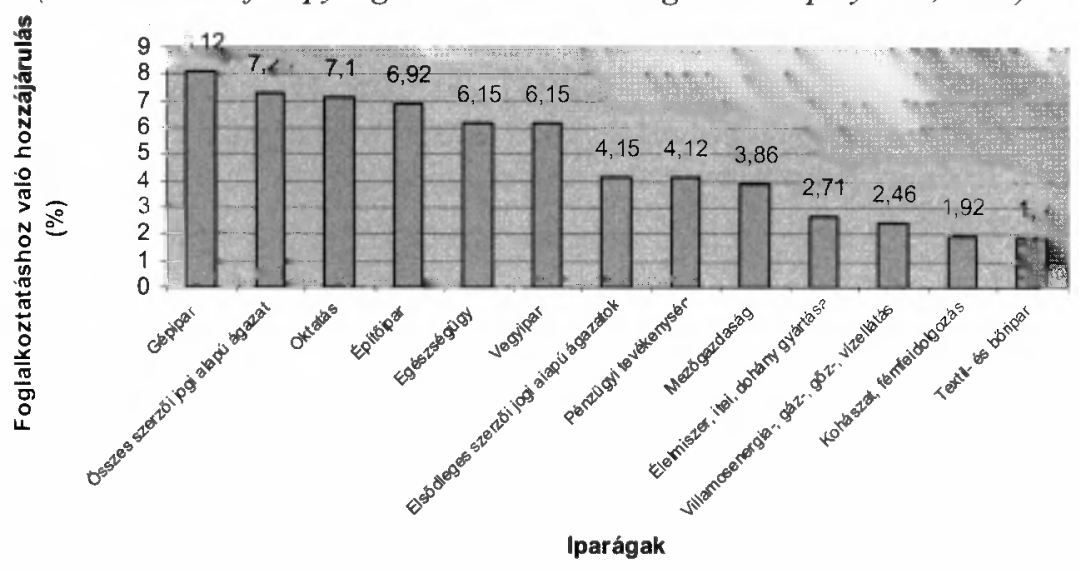

Forrás: Penyigey-Munkácsy (2005).

\section{7. ÁBRA}

Az elsődleges szerzöi jogi ágazatok hozzájárulása a GDP-hez nemzetközi összehasonlításban, 2002 (\%)

(Contribution of the First Copy-rigt Indutries to National GDP in European Economy, 2002)

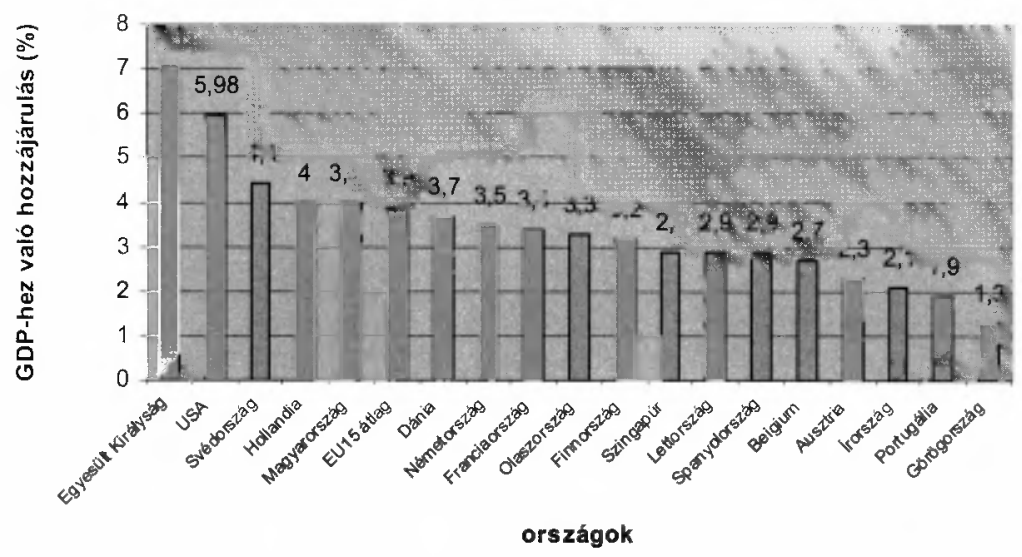

Forrás: Penyigey-Munkácsy (2005).

A kreatív iparágak gazdaságban betöltött szerepét tekintve szoros kapcsolat figyelhető meg a kulturális fogyasztás, illetve a kulturális alapú képzés és a területfejlesztés között. Azokban az országokban, ahol magasabb a kultúrára fordított támogatás, ahol a kulturális szolgáltatásokhoz való hozzáférés magas, és így az állam- 
polgárok kreativitására fordított beruházás jelentősebb, ott a kreatív iparágak GDPben való részesedése arányosan nagyobb.

Fontos megemlítenünk, hogy a kreatív tudástöke hasznosulásának hátterében két veszély állhat, egyrészt a gazdasági értelemben vett szegénység, valamint a hátrányos szocio-kulturális családi háttér. Az alábbi tényezők determinálhatják az egyének kulturális szegénységét, és ezáltal a tudástőke minőségi romlását. Természetesen a problémához hozzájárulhat egy külső tényező is, mégpedig a nem megfelelő képzési rendszer, amely sokszor nem alkalmazkodik elég rugalmasan a munkaeröpiac elvárásainak.

\section{Kreativ gazdaság és kreatív hely}

A kreativitás folyamatát nagyban befolyásolja a kulturális és társadalmi közeg. Ennek alapján hosszú távon az a város, régió vagy ország szerezhet elönyt a globális gazdasági versenyben, amely ennek megfelelően elönyös feltételeket nyrijt a kreativ emberek számára. A kreativ ember tehát a tudását folyton megújítani képes ember, igényes településére, elvár egy inspiratív kulturális miliőt, igényli a szabad alkotás lehetőségét megadó társadalmi környezetet. A kultúra, a társadalom általános klímája és színvonala tehát nemcsak müvelődési lehetőségeket jelent, hanem a tudásalapú gazdaság fő vonzerejét, a versenyképesség egyik fő hajtóerejét (Enyedi 2007).

A kreativ-kulturális gazdaság egyre fokozódó erősödése kapcsán számos tanulmány próbálta feltárni annak befolyásolhatóságát és térbeli megoszlását. A humán tỏke ilyen fokú felértékelödése, annak hatékony kamatoztatásában élenjáró országok sikere feltette a kérdést a recept mibenlétére. Az már évtizedekkel ezelőtt nyilvánvalóvá vált, hogy a kulturális-kreatív iparágak koncentráltsága nagyvárosi környezetben valósul meg. Olyan milioben, ahol egyszerre adottak a fentebb említett módon a magas szintủ oktatás, kulturálódás, az innovatív gazdasági feltételek és a nyitott, befogadó társadalom jelenléte. A többi gazdasági tevékenységhez képest a kreatív gazdaság vonzótényezői némileg mások, letelepedéséhez nem szükségszerü előfeltétel a tömeges nyersanyag és munkaerőigény, valamint a közlekedési viszonyok magas szintủ minősége.

Néhány vizsgálat szerint Európában, a gyarmattartó múltjuk révén, a multikulturalizmusukról elhíresült nyitott, befogadó városokban (Párizs, Amszterdam, London, Milánó) a kreatív gazdaság súlya jóval nagyobb, mint a bezárkózó, etnikailag homogénebb térségekben, városokban (Kovács 2007). Érdekes megfigyelnünk azt is, hogy a termelési struktúrák változásával, a korábbi ipari húzóágazatok leépülésének következtében hanyatló nyugat-európai és észak-amerikai régiók a felzárkózást nem újbóli ipartelepítéssel, hanem kulturális, oktatási, kutatóintézmények kialakításával próbálták ellensúlyozni (pl. Ruhr-vidék, Birmingham oktatási és kulturális komplexumaival, Pittsburgh jelentős kulturális intézményeivel). A sikeres példák követésére már hazánkban is utalnak jelek a volt iparvárosok leépülésének kompenzálásaként (pl. Miskolc). 
A kreatív gazdaság és a tér kapesolatának vizsgálatánál nem kerülhetjük ki Richard Florida (2002) amerikai közgazdász kreativitás és térségfejlesztés kapcsolatában kialakított elméletének bemutatását, mely az új globalizációs trendek alakulása mellett vázolja fel a sikeres gazdaságok jellegzetességeit. Florida kreatív gazdaságról szóló elméletének alaptétele, hogy a gazdasági sikert a térségek, városok helyben gyökerezö erőforrásaiban, lehetőségeinek kiaknázásában látja. Ez a megállapítás elgondolkodtatóvá teszi a magunkhoz hasonló átmeneti gazdaságokat a versenyképesség fokozásának irányába tett lépések megtételénél. Florida egy társadalmi rétegben, a kreativ osztályban véli megtalálni azt a tényezőt, amelynek térségi dominanciája gazdasági fejlödést indukálhat. A szerző ezt a réteget, a magas szintü szellemi tökével rendelkező értelmiséget látja hivatottnak arra, hogy a versenyképesség fenntartható fejlődését indukálja. Kutatásaiban arra vállalkozott, hogy felállítsa az Egyesült Államok nagyvárosainak „kreatív sorrendjét”, majd a kialakult sorrend alapján vizsgálni kezdte a városok gazdasági és életminőségi mutatói, valamint a kreatív osztály jelenléte közötti összefüggéseket.

Az elmélet szerint a sikeres városok és régiók azok, amelyek hosszú távon magukhoz tudják vonzani a kreatív réteget, melynek mobilizálásában három fontos húzótényező játszik szerepet (3T): a Technológia, a Tehetség és a Tolerancia. Florida a technológiai indexet olyan összetett mutatók alapján állította fel, melyben kombinálja a technológiai iparágaknak a helyi gazdasághoz viszonyított arányát és a helyi technológiai iparágaknak a nemzetgazdaság egészéhez viszonyított arányát. Ezzel az indexel a helyi gazdaságok vitalitása alapján rangsorolja a vizsgált térségeket. A tehetség index a régióban bejegyzett szabadalmak száma alapján kerül meghatározásra, mely jól jellemzi a régió kreativitását, a térség technológiai fejlettségét. A harmadik, a többinél sokkal nehezebben meghatározható, de sok esetben a kulcsszerepet betöltő mutató a tolerancia index, mely szerint a térség kreatív gazdaságra építő sikerességének fontos eleme a helyi társadalom másokkal szembeni toleranciája, befogadókészsége, nyitottsága. A három index egyesített mutatószáma a kreativitási index. Elméletének végkövetkeztetése szerint egy régiónak, amely a globális versenyben sikeres kíván lenni, magáévá kell tennie a technológiai fejlödés, a tolerancia és a tehetséggondozás értékeit, kapcsolódva az adott városban elérhető inspiráló miliô intézményi hátteréhez (minőségi oktatási, kulturálódási, szórakozási lehetőségekhez).

A Florida amerikai felméréséhez hasonlóan azóta megszületett egy európai változat is, melyben az Öreg Kontinens országai kerülnek rangsorolásra a kreativitási index alapján (Ságvári-Dessewffy 2006).

Az 1. táblázat alapján egyértelmüen kirajzolódik egy skandináv - észak-európai mezö, ahol a kreatív réteg-vonzóképesség erőteljesebb, mint a déli térségekben. Egybevetve a régió kulturális aktivitásában játszott szerepével, a kulturális fogyasztás mennyiségével hasonló képet kaphatunk. Azok az országok tehát, ahol a kultúrára szánt támogatások és fejlesztések aránya nagyobb, a kreatív gazdaság jelenléte is dominánsabb. Az 1. ábrán található országok között nem szerepel az Egyesült Királyság, holott az országot Európában a kreatív szektor éllovasai között tartják szá- 
mon. Magyarország helyzete a tolerancia index utolsó helye alapján az összesített mutató szerint a hátsó vonalban foglal helyet. A tolerancia értékelése az alábbi adatok tekintetében mutatott lemaradást hazánk szempontjából: tradicionális/szekuláris értékek, túlélés/önkifejezés értékelése, bevándorlók elfogadása, illetve elégedettség alapján.

\section{TÁBLÁZAT}

Az országok rangsora a tehetség, a technológia és a tolerancia index értékei alapján (The Europeans Nations on Talent, Technology, and Tolerance Index)

\begin{tabular}{clccc}
\hline Sorszám & \multicolumn{1}{c}{ Ország } & Tehetség & Technológia & Tolerancia \\
\hline 1. & Svédország & 5. & 1. & 1. \\
2. & Finnország & 1. & 2. & 7. \\
3. & Dánia & 4. & 4. & 2. \\
4. & Svájc & 9. & 3. & 5. \\
5. & Hollandia & 7. & 7. & 3. \\
6. & Belgium & 2. & 9. & 9. \\
7. & Németország & 10. & 5. & 8. \\
8. & Norvégia & 6. & 10. & 4. \\
9. & İrország & 3. & 11. & 16. \\
10. & Ausztria & 15. & 6. & 11. \\
11. & Spanyolország & 11. & 13. & 6. \\
12. & Franciaország & 18. & 8. & 12. \\
13. & Szlovénia & 14. & 14. & 10. \\
14. & Észtország & 8. & 18. & 17. \\
15. & Görögország & 13. & 20. & 15. \\
16. & Olaszország & 24. & 12. & 13. \\
17. & Csehország & 21. & 15. & 14. \\
18. & Litvánia & 12. & 21. & 21. \\
19. & Lettország & 17. & 19. & 20. \\
20. & Portugália & 23. & 17. & 18. \\
21. & Magyarország & 16. & 16. & 25. \\
22. & Szlovákia & 22. & 23. & 19. \\
23. & Lengyelország & 20. & 22. & 23. \\
24. & Bulgária & 19. & 24. & 24. \\
25. & Románia & 25. & 25. & 22. \\
\hline
\end{tabular}

Forrás: Ságvári-Dessewffy (2006).

A kreatív iparágak európai térségi megoszlásában egy észak-déli lejtỏ kirajzolódása tapasztalható, annak ellenére, hogy a köztudottan kulturális tradíciókban, hagyományokban gazdag dél-európai mediterrán térség kulturális vonzóképessége erỏteljesebb. Ennek figyelembevételével magyarázható a kreatív-mutató összetettségének szükségessége. Véleményünk szerint azonban az európai vizsgálatok pon- 
tosabb képet mutattak volna a szektor térségi megoszlásában, ha azok a nagyvárosok megfigyelésére terjedtek volna ki, hiszen az iparágra köztudottan nagyvárosi koncentráltság jellemzö.

\section{Összefoglalás}

A globalizáció jelenségének napjainkra tapasztalható gazdasági-társadalmi trendjeinek következtében a tudás és a kreativitás szerepe a városok, és rajtuk keresztül a régiók fejlődésében jelentősen felértékelödött. Ennek köszönhetően az emberi produktív gondolkodás, a humán tőke a 21. században kiemelkedő gazdasági húzóágazatává emelte a kreatív gazdaságot. A kreativitás felismerése és fejlesztése a nemzeti gazdaságpolitika, a regionális politika egyik fö stratégiai célja kell, hogy legyen a jövő gazdasági versenyképességének fokozása érdekében. A kreativitás nem létezhet légüres térben, megszületéséhez elengedhetetlen az inspiratív környezet, az elfogadó, nyitott társadalom, valamint a helyi gazdaság viszonylagos fejlettsége, támogató-képessége.

A jövőben a humán tőke minőségének javítása érdekében olyan kiemelt területek támogatására is egyre nagyobb szükség van, mint az oktatás és kultúra. Ezen cél eléréséhez elengedhetetlen az állam koordináló szerepének erősítése, hogy az említett területeken a hozzáférhetőség biztosított legyen, a kulturális esélyegyenlőség pedig javuljon.

Az olyan átmeneti gazdaságok számára, mint Magyarország, a humán tókébe való befektetés jelentős jövőbeni sikerekkel kecsegtethet, ha csak arra gondolunk, hogy világviszonylatban - sajnos máshol kamatozva - milyen magas a magyar humántőke-állomány minősége és alkalmazkodóképessége. Ebből következtetve azt tapasztalhatjuk, hogy a szellemi tőkére forditott kiadások megtérülése jóval kedvezőbb, mint nemzetközi szinten. Nem haszontalan tehát követni azon országok gyakorlatát, ahol a technológiai felkészültség, a tehetséggondozás és a nyitott társadalom harmonikus egysége hatékony táptalaját kínálja a kreatív iparágak terjedésének.

\section{Jegyzetek}

'Ennek szemléletes bizonyítéka a 2007 májusában megalkotott elsỏ európai kulturális stratégia, amely kimondja az integráció fenntarthatóságában jelentős szerepet nyeró kultúra fontosságát. A nyilatkozat szerint a kultúra fontos mozgatórugója a személyes fejlődésnek, a társadalmi kohéziónak és a gazdasági növekedésnek, és amely a kreativitás mozgatórugójaként a Lisszaboni Stratégia keretében kiemelten támogatandó terület.

${ }^{2}$ A kultúra fogalmának ugyanis legtágabban vett jelentése tömören az, ami az embert kiemelte az állatvilágból. A kultúra azon szimbólumok, magatartásformák, jelrendszerek, gondolkodásmódok összessége, mely csupán a civilizált emberi faj sajátja.

3 Sajnálatos módon, míg a nyugat-európai országokban, fơként a skandináv térségben az alapszintủ oktatási rendszerben a készségfejlesztó tárgyak oktatására erőteljesebb hangsúlyt helyeznek, hazánkban ezen tárgyak lassú háttérbe kerülése tapasztalható. 


\section{Irodalom}

Creative Industries Economic Estimates Statistical Bulletin. (2006) www.culture.gov.uk Letöltve: 2007. 04. 23.

Enyedi Gy. (2005) A városok kulturális gazdasága. - Enyedi Gy.-Keresztély K. (szerk.) A magyar városok kulturális gazdasága. MTA Társadalomkutató Központ, Budapest. 13-27. o.

Egyedi Gy. (2007) Enyedi Györgynek a Magyar Művelődési Intézet és Képzőművészeti Lektorátus Tudás- Kreativitás-Fejlesztés címủ, 2007. január 31 -én rendezett konferenciáján elhangzott köszöntöje. -SZÍN-Országos Közmüvelödési Folyóirat. 1.3-15. o.

Florida, R. (2002) The Rise of the Creative Class. Basic Books, New York.

Hámori J. (2002) Mit tud az emberi agy? Mindentudás Egyeteme - 7. előadás. (2002. október 28.) www.mindentudas.hu Letöltve: 2007. 04. 05.

Hartley, J. (2005) Creative Industries. - Hartley, J. (ed.) Creative Industries. Blackwell Publishing Ltd., Carlton. 1-40. o.

Klein, B.-Klein, S. (2001) A kreativitás a huszonegyedik század kihivása. www.edge2000.hu Letöltve: 2007. 05. 16.

Kondor Zs. (én.) A kreativitás mintázata: Hajnal István. www.zeus.phil-inst.hu Letöltve: 2007. 02. 09.

Kovács Z. (2007) A tudás szerepe a városfejlódésben: a kreativ város. Konferencia-elöadás a Magyar Múvelỏdési Intézet és Képzömúvészeti Lektorátus Tudás-Kreativitás-Fejlesztés címủ, 2007. január 31 -én rendezett konferenciáján.

Penyigey K.-Munkácsi P. (2005) A szerzói jogi alapú ágazatok gazdasági súlya Magyarországon. Magyar Szabadalmi Hivatal, Budapest.

Ságvári B.-Dessewffy T. (2006) A kreativ gazdaságról - Európa és Magyarország a kreativ korban. Demos Magyarország, Budapest.

Söndermann, M. (2007) Kulturwirtschaft und Creative Industries 2007. Bündnis 90/Die Grünen Bundestagfraktion Info-Dienst, Berlin.

Tájékoztató a kreativitás és a kulturális szegénység témakörében folytatott kutatásokról. www.allamreform.hu Letöltve: 2007. 05. 21.

Z. Karvalics L.-Kollányi B. (2006) Humán töke és versenyképesség. - Vértes A.-Viszt E. (szerk.) Tanulmányok Magyarország versenyképességéról. Új Mandátum Könyvkiadó, Budapest. 109-133. o.

\section{GLOBALISATION AND THE REVALUATION OF CREATIVE ECONOMY}

\section{ESZTER DOBÓ}

Today's world of globalisation witnesses a rise in value of cultural and creative industries. The restructuring of the world economy involved a greater emphasis on intellectual capital and creativity. However, values that can be created through productive thinking are results of cultural processes. Thus highlighting culture has bacome economic necessity in crisis management strategies of postindustrial societies, increasing competitiveness, at the same time strengthening social cohesion. 